Magna Scientia Advanced Research and Reviews

eISSN: 2582-9394

Cross Ref DOI: $10.30574 / \mathrm{msarr}$

Journal homepage: https://magnascientiapub.com/journals/msarr/

Check for updates

(RESEARCH ARTICLE)

\title{
Comparative assessment of the anti-diarrhoeal effects of the ethanol leaf and stem extracts of lantana camara in Wistar rats
}

Joseph Olanrewaju Oyindamola, Godwin Christian Akuodor, Malachy Ifeanyi Obi, Evelyn Ogochukwu Nwachukwu, Kingsley Chimsorom Chilaka *, Omo Eric Irinmwinuwa

Department of Pharmacology and Therapeutics, Faculty of Medicine, College of Health Sciences, Nnamdi Azikiwe University, Nnewi Campus, Nigeria.

Magna Scientia Advanced Research and Reviews, 2021, 03(01), 035-045

Publication history: Received on 05 August 2021; revised on 26 September 2021; accepted on 28 September 2021

Article DOI: https://doi.org/10.30574/msarr.2021.3.1.0059

\begin{abstract}
The antidiarrhoeal effects of Lantana camara ethanol leaf and stem extracts were compared in Wistar rats. The phytochemical and acute toxicity tests were also determined. The extracts were evaluated for castor oil- induced diarrhoea and enteropooling as well as intestinal transit in rats. The ethanol stem extract produced significant $(P<$ $0.05)$, while the ethanol leaf extract produced significant $(P<0.01)$ dose dependent protection on rats against castor oil induced diarrhoea. The stem extract inhibited intestinal transit time and caused significant $(P<0.05)$, while leaf extract caused significant $(P<0.01)$ dose related inhibition of castor oil induced enteropooling in rats, comparable to the standard drugs. The leaf and stem extracts significantly and dose dependently delayed the onset of castor oil induced diarrhoea, decreased the frequency of defecation and reduced the severity of diarrhoea in rats. The ethanol leaf and stem extracts of L. camara significantly and dose dependently decreased the volume of intestinal fluid accumulation in the castor oil induced enteropooling. The distance travelled by charcoal meal in intestinal transit time was also reduced.

The oral LD50 values obtained were greater than $5000 \mathrm{mg} / \mathrm{kg}$ in rats. These findings suggest that both ethanol leaf and stem extracts of Lantana camara may contain some biologically active ingredients that are active for the treatment of diarrhoea in Nigerian herbal traditional medicine. However, the leaf extract has more antidiarrhoeal activities compared to the stem extract in castor oil-induced diarrhoeal in Wistar rats.
\end{abstract}

Keywords: Lantana camara; Leaf; Stem; Diarrhoea; Rats

\section{Introduction}

Diarrhoea is one of the most common and serious diseases in almost all tropical countries of the world, being the principal cause of morbidity and mortality as a result of fluid loss and severe dehydration among children in the developing countries $[1,2,3]$. It is usually a result of gastrointestinal infection, which can be caused by a variety of bacterial (Escherichia coli, Vibrio cholerae, Shigella species etc.), viral (Rota virus, Norovirus, Cytomegalovirus etc.) and parasitic organisms (protozoa and helminthes) [4]. Infection is spread through contaminated food or drinking water, or from person to person as a result of poor personal hygiene. Diarrhoea can also be caused by food intolerance, food poisoning or as a side effect of certain medications [5]. Despite different pathophysiological changes in different types of diarrhoea, there are four major mechanisms responsible for pathophysiology in electrolyte and water transport that is, increased luminal osmolarity, increased electrolyte secretion, decreased electrolyte absorption and accelerated intestinal motility causing decreased transit time [6]. To combat this problem, the world health organization (WHO) has initiated a diarrhoeal disease control program to study traditional medicine practices and other related aspects,

\footnotetext{
${ }^{*}$ Corresponding author: Kingsley Chimsorom Chilaka

Department of Pharmacology and Therapeutics, Faculty of Medicine, College of Health Sciences, Nnamdi Azikiwe University, Nnewi Campus, Nigeria.
}

Copyright $(2021$ Author(s) retain the copyright of this article. This article is published under the terms of the Creative Commons Attribution Liscense 4.0. 
together with the evaluation of health education and prevention approaches [2]. Currently, approximately $25 \%$ of drugs are derived from plants, and others are synthetic analogs built on prototype compounds isolated from plant species in modern pharmacopoeia [6].

Lantana camara is a flowering ornamental plant belonging to family Verbenaceae. In Nigeria, L. camara has local names "Ewonadele" in Yoruba, "Kimbamahalba" in Hausa, and "Anya nnunu" in Igbo [7]. Lantana camara is the most widespread species of this genus, which grows productively at elevations up to $2000 \mathrm{~m}$ in tropical, sub-tropical and temperate regions [8]. It is a medium sized aromatic shrub with tetra-angular stem. The plant grows up to 1 to 3 meters and it can spread to 2.5 meters in width. The leaves are generally oval or broadly lance shaped and has a yellow-green to green color. Leaves and stem are covered with rough hairs and different parts are used for different purposes [9]. Studies revealed that Lantana camara has been proven to have activities against diarrhoeal causing microorganisms including antibacterial, antifungal and anthelmintic activities [10, 11, 12]. In addition, it also possesses antimycobacterial, antioxidant, antinociceptive and anti-inflammatory, antimalarial, antiulcerogenic, and anti-leishmaniasis activities [13, $14,15,7,16,17]$. In vivo studies indicate the leaves of L.camara and its constituents (Lanthadne A), have antimotility and antidiarrhoeal activity in mice model of diarrhoea $[18,19]$. Furthermore, in vitro study on excised rat ileum also indicates this plant showed antispasmodic activity by antagonizing the actions of acetylcholine and substances which can alleviate spasm of the gastrointestinal muscles have been postulated to have antidiarrhoeal activity [20].

This study therefore, compared and validated the traditional use of the leaf and stem of this plant and further ascertained in which part the constituents responsible for antidiarrhoeal activities are concentrated so as to provide a clue about the nature of the phytochemical constituents responsible for its action.

\section{Material and methods}

\subsection{Plant Collection}

Fresh leaves and stem of Lantana camara were harvested from a farmland in Umumejiaku, Uruagu, Nnewi North Local Government Area, Anambra State. The plant was identified and authenticated by a taxonomist in the Department of Pharmacognosy and Traditional Medicine, Faculty of Pharmaceutical Sciences, Nnamdi Azikiwe University, Agulu Campus. A voucher sample with (herbarium number PCG/474/A/029) was prepared and deposited in the herbarium of Pharmacognosy department for reference.

\subsection{Preparation of plant extract}

The leaves and stem of L. camara were air dried for 7 days at room temperature and pulverized into powder separately, using Warring commercial blender. Seven hundred grams (700 g) of the coarse powder and six hundred (600 g) of $L$. camara leaves and stems were weighed by sensitive digital weighing balance. The coarse powders were soaked separately in different flask containing $80 \%$ ethanol $(1.5 \mathrm{~L})$ each and then placed on a shaker with occasional shaking for $48 \mathrm{~h}$ at room temperature. The extracts were filtered and the filtrates dried on a water bath at reduced temperature of $40{ }^{\circ} \mathrm{C}$ and a yield of $8 \mathrm{~g}$ of the dry leaf extract with greenish colour and $12 \mathrm{~g}$ dry stem extract with brownish colour. The extract was reconstituted in distilled water at appropriate concentrations for the various experiments conducted.

\subsection{Experimental Animals}

Healthy Wistar rats were purchased from the Animal House of Nnamdi Azikiwe University, Agulu Campus, Anambra State for the study. The animals weighing between 180 and 200 grams were randomly divided into five treatment groups. They were housed in plastic cages ( 5 rats in each cage) with free access to food and water ad libitum. They were maintained under standard laboratory conditions of relative humidity and room temperature of $25{ }^{\circ} \mathrm{C}$. All rats were acclimatized to the working environment for 7 days before the pharmacologic evaluation. National Institute of Health Guide for the Care and Use of Laboratory Animal was adopted for the animal protocol of this study [21]. Acute toxicity test

\subsection{Acute toxicity test}

Oral acute toxicity test was performed using the Organization of Economic Cooperation and Development (OECD) 401 guideline for testing of chemicals [22]. Male and female rats weighing 180-200 g were used for this study, and were conducted in two phases. Three groups of 3 rats (male separated from female) in each cage were administered 10 $\mathrm{mg} / \mathrm{kg}, 100 \mathrm{mg} / \mathrm{kg}$ and $1000 \mathrm{mg} / \mathrm{kg}$ of the L. camara leaf and stem extract orally. The rats were observed for signs of toxicity and mortality for $24 \mathrm{~h}$ with special attention given to the first $4 \mathrm{hrs}$. This was followed by administration of the extract $(1600 \mathrm{mg} / \mathrm{kg}, 2900 \mathrm{mg} / \mathrm{kg}$ and $5000 \mathrm{mg} / \mathrm{kg}$ ) to the next three groups of 1 rat and equally observed as earlier 
stated, and daily for 7 days for any signs of toxicity which include salivation, paw-licking, writhing, change in body weight and mortality. The number of deaths in each group was recorded and the final LD50 values were calculated.

\subsection{Preliminary Phytochemical Screening}

The crude extract of L. camara leaf and stem were subjected to qualitative phytochemical screening according to standard methods [23, 24].

\subsection{Castor oil-induced diarrhoeal model}

The procedure outlined by Qnais et al [25] was used for the test. The animals kept at $25^{\circ} \mathrm{C}$ were fasted for $24 \mathrm{~h}$ but had access to water prior to the commencement of the experiment. Each animal (rat) was placed in a separate cage with blotting paper lined on the floor. The animals in the first (negative control), second, third, fourth, and fifth (positive control) groups, were orally administered with $20 \mathrm{~mL} / \mathrm{kg}$ distilled water; $200 \mathrm{mg} / \mathrm{kg}, 400 \mathrm{mg} / \mathrm{kg}$, and $600 \mathrm{mg} / \mathrm{kg}$ of the L. camara extract; and $4 \mathrm{mg} / \mathrm{kg}$ of loperamide, respectively. At 30 mins after treatment, each of the rats was orally given $1 \mathrm{~mL}$ of castor oil. The severity of diarrhoea was monitored for a period of $5 \mathrm{hrs}$. The total number of diarrhoea (drops) was recorded and compared with the controls. The percentage (\%) inhibition of diarrhoea was calculated following the formula [26] below

$$
\% \text { inhibition of defecation }=\frac{A-B}{A} \times 100
$$

Where A is the mean number of defecation caused by castor oil, and B is mean number of defecation caused by drug or extract.

\subsection{Gastrointestinal motility model (Charcoal meal)}

The method described by Akuodor et al. [27] was used. Fasted rats (as previously described) were divided into five groups of five rats in each cage. The negative control group received $1020 \mathrm{~mL} / \mathrm{kg}$ of distilled water orally. Animals in the second, third, and fourth groups received $200 \mathrm{mg} / \mathrm{kg}, 400 \mathrm{mg} / \mathrm{kg}$, and $600 \mathrm{mg} / \mathrm{kg}$ of the crude extracts, respectively, whereas those in the positive control received atropine sulphate $(5 \mathrm{mg} / \mathrm{kg})$. After $30 \mathrm{mins}$, the animals were all given 1 $\mathrm{mL}$ of charcoal meal (10\% charcoal suspension in $5 \%$ tragacanth) orally. Lastly, after 30 mins, all the rats were sacrificed and the abdomen opened. The small intestine was dissected out from the pylorus to the caecum and the total distance traveled by the charcoal plug along the small intestine was estimated for both the control and the treated groups. The percentage distance traveled by the charcoal meal from the pylorus to the caecum was calculated following formula [26] below.

$$
\% \text { inhibition }=\frac{\text { mean length of intestine }- \text { mean distance traveled by meal }}{\text { mean length of intestine }} \times 100
$$

\subsection{Castor oil-induced intestinal fluid accumulation model}

The procedure described by Akuodor et al. [28] was adopted in the castor oil-induced intestinal fluid accumulation model. The test animals were deprived of food for $24 \mathrm{~h}$ prior to the study. They were assigned into five groups of five animals each. Animals in the positive and negative control groups orally received $4 \mathrm{mg} / \mathrm{kg}$ of loperamide and $20 \mathrm{~mL}$ of distilled water, respectively, whereas those in the test groups respectively received $200 \mathrm{mg} / \mathrm{kg}, 400 \mathrm{mg} / \mathrm{kg}$, and 600 $\mathrm{mg} / \mathrm{kg}$ of the leaf and stem extracts. Immediately after these administrations, $1 \mathrm{~mL}$ of castor oil was administered orally to each rat in all the groups. After $30 \mathrm{mins}$, the rats were sacrificed. The small intestine was excised and the intestinal contents were milked quantitatively into a measuring cylinder to obtain the volume of the intestinal content. The percentage of inhibition of intestinal content was determined by using the following formula [26].

$$
\% \text { inhibition of intestinal fluid }=\frac{\text { control }- \text { test extract }}{\text { control }} \times 100
$$

\subsection{Statistical Analysis}

Results were expressed as means \pm SEM and analyzed with statistical package for social sciences (SPSS version 20) by using one-way analysis of variance (ANOVA) followed by Dunnett's post hoc test. Difference in the mean $P<0.05$ was statistically considered significant. 


\section{Results}

\subsection{Phytochemical screening}

Phytochemical analysis of the ethanol extract of L. camara stem gave positive reaction for each of the following secondary metabolites: Tannins, Saponins, Steroids, Alkaloids, Flavonoids and Glycosides. While the leaf revealed the presence of Tannins, Saponins, Terpenoids, Steroids, Alkaloids and Flavonoids.

\subsection{Acute toxicity test}

The ethanol leaf and stem extracts of Lantana camara did not produce any lethality or significant signs of toxicity in rats up to $5000 \mathrm{mg} / \mathrm{kg}$ body weight for 24 and $72 \mathrm{~h}$ post treatment.

\subsection{Antidiarrhoeal effect of the ethanol crude extracts and fractions in rats}

The $200 \mathrm{mg} / \mathrm{kg}, 400 \mathrm{mg} / \mathrm{kg}$ and $600 \mathrm{mg} / \mathrm{kg}$ of ethanol leaf and stem crude extracts of L. camara produced a dosedependent and significant protection of rats against castor oil-induced diarrhoea, which led to the decreased number of feces. Both crude extracts delayed the onset of castor oil-induced diarrhoea, decreased the frequency of defecation (number of wet feces and total number of feces), and reduced the severity of diarrhoea in the rats. Results from the experiment revealed that $600 \mathrm{mg} / \mathrm{kg}$ of ethanol leaf extract of L. camara produced the highest inhibitory effect, showed the maximum percentage inhibition of defecation and the lowest percentage of mean fecal output when compared with the stem crude extract and Loperamide ( $4 \mathrm{mg} / \mathrm{kg}$ ); a standard antidiarrhoeal drug (Table 1 and 2).

\subsection{Intestinal transit in rats}

All the treated groups inhibited intestinal transit and delayed gastric emptying. The oral administration of the crude extracts produced dose-dependent and significantly $(\mathrm{p}<0.05)$ slowed the propulsive movement and transit charcoal meal. The $600 \mathrm{mg} / \mathrm{kg}$ of the leaf crude extracts showed more antimotility effect than the atropine sulphate at $5 \mathrm{mg} / \mathrm{kg}$ and $600 \mathrm{mg} / \mathrm{kg}$ of the stem crude extracts used. However, the maximum effect was achieved by the leaf crude extract at $600 \mathrm{mg} / \mathrm{kg}(71 \%)$ when compared with the stem crude extract at $600 \mathrm{mg} / \mathrm{kg}(61 \%)$ as shown in Tables 3 and 4.

\subsection{Intestinal fluid accumulation in rats}

The ethanol extracts doses dependently and significantly decreased the volumes of intestinal fluid with corresponding increase in inhibition of the intestinal fluid content in the castor oil-induced intestinal fluid accumulation model. The intestinal fluids of the animals pre-treated with the ethanol leaf and stem extracts of L. camara as well as loperamide were found to be more viscous than those of the rats treated with distilled water. The highest percentage inhibition of intestinal fluid content was achieved by the leaf extract at $600 \mathrm{mg} / \mathrm{kg}$ (85\%) when compared with stem crude extract at $600 \mathrm{mg} / \mathrm{kg}$ (75\%) as shown in Tables 5 and 6.

Table 1 Effect of leaf extract of L. camara on castor oil-induced diarrhoea in rats

\begin{tabular}{|l|c|c|c|}
\hline Drug & Dose $\mathbf{( m g / k g )}$ & Mean frequency of diarrhoea (4 h) & \% Inhibition \\
\hline Distilled water & $20 \mathrm{ml} / \mathrm{kg}$ & $9.00 \pm 0.45$ & - \\
\hline L. camara & 200 & $2.34 \pm 1.00$ & $74^{\mathrm{a}}$ \\
\hline L. camara & 400 & $1.98 \pm 0.86$ & $78^{\mathrm{a}}$ \\
\hline L. camara & 600 & $1.35 \pm 0.58$ & $85^{\mathrm{b}}$ \\
\hline Loperamide & 4 & $1.53 \pm 0.64$ & $83^{\mathrm{b}}$ \\
\hline
\end{tabular}

Values expressed as mean \pm SEM $(n=5)$; asignificantly different from control at $\mathrm{P}<0.05$; bsignificantly different from control at $\mathrm{P}<0.01$. 
Table 2 Effect of stem extract of L. camara on castor oil-induced diarrhoea in rats

\begin{tabular}{|l|c|c|c|}
\hline \multicolumn{1}{|c|}{ Drug } & Dose $\mathbf{( m g / k g )}$ & Mean frequency of diarrhoea (4 h) & \% Inhibition \\
\hline Distilled water & $20 \mathrm{ml} / \mathrm{kg}$ & $10.00 \pm 1.26$ & - \\
\hline L. camara & 200 & $4.60 \pm 0.68$ & $54^{\mathrm{a}}$ \\
\hline L. camara & 400 & $4.00 \pm 0.46$ & $60^{\mathrm{a}}$ \\
\hline L. camara & 600 & $3.20 \pm 0.37$ & $70^{\mathrm{b}}$ \\
\hline Loperamide & 4 & $1.60 \pm 0.60$ & $84^{\mathrm{b}}$ \\
\hline
\end{tabular}

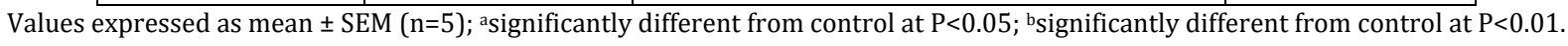

Table 3 Effect of leaf extract of L. camara on intestinal motility in rats

\begin{tabular}{|l|c|c|c|c|}
\hline Drug & Dose (mg/kg) & $\begin{array}{l}\text { Mean intestinal } \\
\text { Length } \mathbf{( c m )}\end{array}$ & $\begin{array}{l}\text { Mean distance travelled } \\
\text { by marker } \mathbf{( c m})\end{array}$ & $\begin{array}{l}\text { \% } \\
\text { Inhibition }\end{array}$ \\
\hline Distilled water & $20 \mathrm{ml} / \mathrm{kg}$ & $109.40 \pm 4.85$ & $97.00 \pm 3.87$ & - \\
\hline L. camara & 200 & $98.4 \pm 2.29$ & $51.6 \pm 2.13$ & $48^{\mathrm{a}}$ \\
\hline L. camara & 400 & $95.60 \pm 3.00$ & $42.20 \pm 1.68$ & $56^{\mathrm{a}}$ \\
\hline L. camara & 600 & $94.4 \pm 2.58$ & $27.66 \pm 0.87$ & $71^{\mathrm{a}}$ \\
\hline Atropine & 5 & $93.00 \pm 2.00$ & $27.60 \pm 1.43$ & $70^{\mathrm{a}}$ \\
\hline
\end{tabular}

Values expressed as mean \pm SEM ( $n=5$ ); asignificantly different from control at $\mathrm{P}<0.05$; bsignificantly different from control at $\mathrm{P}<0.01$.

Table 4 Effect of stem extract of L. camara on intestinal motility in rats

\begin{tabular}{|l|c|c|c|c|}
\hline Drug & Dose (mg/kg) & $\begin{array}{l}\text { Mean intestinal } \\
\text { Length } \mathbf{( c m )}\end{array}$ & $\begin{array}{l}\text { Mean distance travelled } \\
\text { by marker (cm) }\end{array}$ & $\begin{array}{l}\text { \% } \\
\text { Inhibition }\end{array}$ \\
\hline Distilled water & $20 \mathrm{ml} / \mathrm{kg}$ & $106.40 \pm 1.29$ & $98.40 \pm 1.69$ & - \\
\hline L. camara & 200 & $97.63 \pm 1.93$ & $57.6 \pm 1.43$ & $41^{\mathrm{a}}$ \\
\hline L. camara & 400 & $98.72 \pm 0.86$ & $46.40 \pm 1.75$ & $53^{\mathrm{a}}$ \\
\hline L. camara & 600 & $99.49 \pm 2.70$ & $38.80 \pm 1.16$ & $61^{\mathrm{a}}$ \\
\hline Atropine & 5 & $96.88 \pm 1.71$ & $31.00 \pm 2.56$ & $68^{\mathrm{a}}$ \\
\hline
\end{tabular}

Table 5 Effect of leaf extract of L. camara on castor oil-induced intestinal fluid accumulation in rats

\begin{tabular}{|l|c|c|c|}
\hline Drug & Dose (mg/kg) & $\begin{array}{l}\text { Volume of intestinal } \\
\text { content (ml) }\end{array}$ & $\begin{array}{l}\text { \% } \\
\text { Inhibition }\end{array}$ \\
\hline Distilled water & $20 \mathrm{ml} / \mathrm{kg}$ & $3.68 \pm 0.29$ & - \\
\hline L. camara & 200 & $1.06 \pm 0.11$ & $71^{\mathrm{a}}$ \\
\hline L. camara & 400 & $0.74 \pm 0.12$ & $80^{\mathrm{a}}$ \\
\hline L. camara & 600 & $0.55 \pm 0.24$ & $85^{\mathrm{b}}$ \\
\hline Loperamide & 4 & $0.59 \pm 0.00$ & $84^{\mathrm{b}}$ \\
\hline
\end{tabular}


Table 6 Effect of stem extract of L. camara on castor oil-induced intestinal fluid accumulation in rats

\begin{tabular}{|l|c|c|c|}
\hline \multicolumn{1}{|c|}{ Drug } & Dose $\mathbf{( m g / k g )}$ & $\begin{array}{c}\text { Volume of intestinal } \\
\text { content }(\mathbf{m l})\end{array}$ & $\begin{array}{c}\text { \% } \\
\text { Inhibition }\end{array}$ \\
\hline Distilled water & $20 \mathrm{ml} / \mathrm{kg}$ & $3.14 \pm 0.37$ & - \\
\hline L. camara & 200 & $1.24 \pm 0.08$ & $61^{\mathrm{a}}$ \\
\hline L. camara & 400 & $1.04 \pm 0.05$ & $67^{\mathrm{a}}$ \\
\hline L. camara & 600 & $0.78 \pm 0.10$ & $75^{\mathrm{b}}$ \\
\hline Loperamide & 4 & $0.62 \pm 0.08$ & $80^{\mathrm{b}}$ \\
\hline
\end{tabular}

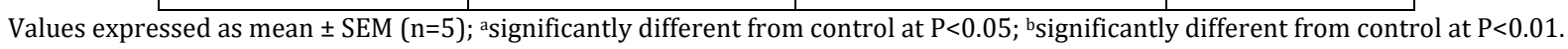

\section{Discussion}

Diarrhoea is usually considered a result of altered motility and fluid accumulation within the intestinal tract leading to morbidity and mortality among children in the developing countries [3]. Despite the presence of a vast spectrum of approaches for controlling diarrhoea, the majority of people in many developing countries rely on herbal agents for the management of the disease [26]. Many plants in Nigeria have been reported to be effective against diarrhoea and dysentery as they are used by local communities as traditional folklore medicine.

In the herbal medicine system, the leaf and stem L. camara has been used in diarrhoea management $[18,29,19,3]$. Despite its traditional usage as an antidiarrhoeal agent, there is no available information regarding the part that is more effective in controlling diarrhoea. Hence, the present study sought to assess this. The castor oil used in the models induces diarrhoea through a pathophysiological mechanism induced by its active metabolite, ricinoleic acid. Castor oil is enzymatically metabolized into recinoleic acid, a hydroxylated fatty acid in the intestinal lumen and considerable amounts of ricinoleic acid is absorbed in the intestine [30]. The ricinoleic acid released causes irritation and inflammation of intestinal mucosa, leading to the liberation of inflammatory mediators, like histamine, prostaglandins, and others [31]. The metabolite initiates diarrhoea by binding with EP3 prostanoid receptors on smooth muscle cells [32]. However, the liberated prostaglandins promote vasodilatation, mucus secretion, and contraction of the smooth muscles in the small intestines. The prostaglandin E series is known to be diarrhoeagenic agents in both laboratory animals and in human beings. Studies showed that ricinoleic acid increases sodium and water secretion through its ultrastructural alterations in the villous tips of the intestinal mucosa [33]. Castor oil (ricinoleic acid) impairs normal intestinal fluid absorption through inhibition of intestinal $\mathrm{Na}^{+} / \mathrm{K}^{+}$ATPase activity [34] and also alters the motility of GI smooth muscles [35]. The use of castor oil, therefore, to induce diarrhoea in this studies is valid as it mimics the pathophysiologic processes.

It is well-documented that loperamide antagonizes the diarrhoea induced by castor oil and these actions are due to antisecretory and antimotility properties [36]. Charcoal passage test is commonly used to determine the effect of the test substances on gut motility. Atropine blocks M1 receptors on gastric parietal cells and helps in reduction of gastric secretions. Furthermore, it blocks M3 receptors on visceral smooth muscles of stomach and intestine leading to relaxation of these muscles and decrease the tone and amplitude of these organs [37]. Hence, atropine was used as standard antisecretory drug for comparison in charcoal passage test.

As shown in Tables 1 and 2, although, the three serial doses of both extracts were found to produce a reduction in the frequency of defecation and diarrheal output to the same significant level that was produced by loperamide, but, the leaf extract significantly $(p<0.01)$ reduced the total fecal output and diarrhoeal drops in castor oil-treated rats in the four-hour observation compared with the stem extract. The percentage reduction in the frequency of defecation and diarrhoea was increased with a corresponding increase in the dose of the leaf and stem extracts.

The percentage inhibition (85\%) produced by the highest dose of the leaf extract ( $600 \mathrm{mg} / \mathrm{kg}$ ) was greater than the inhibition produced by loperamide (84\%) and the stem extract (70\%) at the highest dose of $600 \mathrm{mg} / \mathrm{kg}$. This increasing pattern of percentage inhibition in the total number of fecal output instances with increasing dose of the extracts implies that they inhibit diarrhoea more effectively at relatively higher doses [38]. The antidiarrheal activity of the plant might be due to the activities that oppose the actions of castor oil for induction of diarrhoea or pathophysiologic processes leading to diarrhoea. 
Mostly, antidiarrhoeal agents act by decreasing secretion and/or reducing the propulsive movement of GI smooth muscles. So to further get information about the mechanism for the antidiarrhoeal activity, the extracts were evaluated by GI motility and intestinal fluid accumulation tests.

In the gastrointestinal motility test model (Tables 3 and 4), the ethanol leaf and stem of L. camara extracts reduced gastrointestinal motility in castor oil-treated rats as shown by reduction in gastrointestinal movement of charcoal meal. The extracts caused a significant reduction in the gastrointestinal charcoal meal transit at $400 \mathrm{mg} / \mathrm{kg}$ and $600 \mathrm{mg} / \mathrm{kg}$ doses compared with the negative controls. The percentage inhibition (71\%) produced by the highest dose of the leaf extract $(600 \mathrm{mg} / \mathrm{kg})$ was greater than the inhibition produced by Atropine $(70 \%)$ and the stem extract $(61 \%)$ at its highest doses of $600 \mathrm{mg} / \mathrm{kg}$. These findings indicate that the gastrointestinal motility was greatly decreased as the dose of the extracts increased with the leaf extract having the highest antimotility effect.

Similar to the findings in the castor oil-induced diarrhoea model, all doses of the plant extracts showed a significant reduction in the volume of intestinal fluid compared with the negative controls as shown in Tables 5 and 6 . The percent reduction in volume of intestinal content was increased with the dose of the extracts. This result demonstrated that the effect of the plant extracts on percent inhibition of castor oil-induced intestinal fluid accumulation is increased as its dose was increased. The results in this model revealed that the effect of the highest dose of the leaf extract (600 mg/kg) on intestinal fluid accumulation was found to be greater than the inhibitory effect of loperamide, and stem extract at the highest dose of $600 \mathrm{mg} / \mathrm{kg}$. The findings in this model indicate that the leaf extract has more significant antisecretory effect and this contributes to its antidiarrhoeal effect noted in castor oil-induced diarrhoea model.

The Lantana camara leaf and stem extracts have been shown to decrease the intestinal fluid accumulation. This suggests that the plant extracts may decrease water and electrolyte secretion to the intestinal lumen while promoting their absorption, which in turn could decrease intestinal overload and distension, leading to a decrease in intestinal motility (giving a longer time for absorption) and water contents of the fecal drops and hence overall reduction in the total number of defecation instances and diarrhoeal drops in treated groups. This is consistent with the mechanism of action of loperamide for its antidiarrheal effect as presented in the literatures [39]. Furthermore, the extracts may have an anticholinergic activity and cause reduction in intestinal motility and secretion, which is in agreement with the action of atropine on the intestine [40]. So, the antidiarrhoeal effect of the plant leaf and stem extracts may be attributed to, at least in part, its antimotility activity.

The ethanol extract of L. camara stem contains flavonoids, alkaloids, tannins, steroids, saponin and glycosides, while the ethanol extract of L. camara leaf revealed the presence of flavonoids, alkaloids, tannins, steroids, saponin and terpenoids, as asserted by preliminary phytochemical screening tests, and most of these secondary metabolites were reported to have an antidiarrhoeal activity. Reports in the literatures showed that terpenoids, flavonoids and tannins inhibit the active secretion of ricinoleic acid, resulting in the activation of $\mathrm{Na}^{+}, \mathrm{K}^{+}$ATPase activity that promotes absorption of $\mathrm{Na}^{+}$and $\mathrm{K}^{+}$in the intestinal mucosa [34] which is linked with a decrease in frequency of feces. They are shown to promote colonic absorption of water and electrolytes [41]. Studies showed that ricinoleic acid might activate the nitric oxide pathway and induce nitric oxide (NO) dependent gut secretion [42, 43]. Other studies also confirmed that NO is involved in the causation of diarrhoea and this is counteracted by agents that inhibit NO synthesis [44]. A previous study indicates that different solvent extracts of L. camara inhibit NO synthesis through suppression of iNOS protein [45]. In addition, phytochemical constituents such as flavonoids [46, 47], tannins (48) and alkaloids [49] are implicated in the inhibition of nitric oxide synthesis by suppressing the expression of iNOS enzyme.

The significant effect of leaf extract to reduce the weight of intestinal content at $600 \mathrm{mg} / \mathrm{kg}$ compared with the stem extract at $600 \mathrm{mg} / \mathrm{kg}$ might be due to the accumulation of terpenoids that possess inhibitory effect on NO production [50].

Both extracts in the castor oil induced GI motility test significantly slowed down charcoal meal transit in the GIT, showing that they could have inhibitory effects on the excitatory neurotransmitters in the GIT thus leading to relaxation of the gut muscles and slowing down motility [51]. This assumption is further supported by the antispasmodic activity of the leaf extract of this plant by antagonizing the actions of acetylcholine [18]. Tannins which are present in both extracts have been demonstrated to inhibit GI movement by reducing the intracellular $\mathrm{Ca}^{2+}$ inward current or by activation of the calcium pumping system [52] as well as by forming protein tannates, which make the intestinal mucosa more resistant and hence, reduce peristaltic movement [53]. The presence of terpenoids in the leaf extract demonstrated antispasmodic activity and have an inhibitory effect on GI motility [54]. 
Moreover, both plant extracts were found to be safe as no sign of toxicity was noted in the acute oral toxicity test. This indicates that the plant is tolerable and safe even at higher doses used in the three antidiarrheal models of this study. This validates the safety of the plant in its use in the traditional settings as well.

\section{Conclusion}

The results in this experimental study indicates that L. camara leaf and stem ethanol extracts possess antidiarrhoeal activities. The findings therefore show that the leaf extract possesses more antidiarrhoeal activity than the stem extract. However, further studies are now under way to isolate, characterize and determine the structure of the plant active constituents.

\section{Compliance with ethical standards}

\section{Acknowledgments}

The authors are grateful to the technologists of Department of Pharmacology and Therapeutics, Faculty of Medicine, College of Health Sciences, Nnamdi Azikiwe University, Nnewi Campus, for their technical assistance.

\section{Disclosure of conflict of interest}

No conflict of interest is associated with this study.

\section{Statement of ethical approval}

The study was conducted according to the Animal Ethical Committee Guidelines of Nnamdi Azikiwe University Teaching Hospital, Nnewi Campus, Anambra State (NAUTH/CS/66/VOL.14/VER.3/291/2021/069) and every effort was made to minimize animal suffering.

\section{References}

[1] Liu L, Johnson HL, Cousens S, Perin J, Scott S, Lawn JE, Rudan I, Campbell H, Cibulskis S, Li M, Mathers C, Black RE. Child Health Epidemiology Reference Group of WHO and UNICEF. Global, regional and national causes of childmortality: an updated systematic analysis for 2010 with time trends since 2000. Lancet. 2012; 379: 21512161.

[2] WHO. Diarrhoeal disease. 2020.

[3] Tadesse E, Engidawork E, Nedi T, Mengistu G. Evaluation of the anti-diarrhoeal activity of the aqueous stem extract of Lantana camara Linn (Verbenaceae) in mice. BMC Complementary and Alternative Medicine. 2017; 17: 190.

[4] WGO practice guideline. Acute diarrhoea. 2020.

[5] Nansunga M, Barasa A, Abimana J, Alele PE, Kasolod J. Safety and antidiarrhoealactivity of Priva adhaerens aqueous leaf extract in a murine model. Journal of Ethnopharmacology. 2014; 251-256.

[6] Bahekar SE, Kale RS. Antidiarrhoeal activity of ethanolic extract of Manihot esculenta Crantz leaves in Wistar rats. Journal of Ayurveda \& Integrative Medicine. 2015; 6: 35-40.

[7] Gabi B, Adewumi AAJ, Aina VO. Phytochemical characterization and in-vivo antimalaria activity of Lantana camara leaf extract. British Journal of Pharmacology and Toxicology. 2011; 2: 277-282.

[8] Kalita S, Kumar G, Karthik L, Venkata K Rao B. A review on medicinal properties of Lantana camara leaf. Research Journal of Pharmacy and Technology. 2012; 5: 711-715.

[9] Sangeetha M, Mahendran C, Ushadevi C. An overview of the medicinal properties of lantana camara linn. International Journal of Innovative Pharmaceutical Sciences and Research. 2015; 3: 645-654.

[10] Salada JT, Balala LM, Vasquez EA. Phytochemical and antibacterial studies of Lantana camara L. leaf fraction and essential oil. International Journal of Scientific and Research Publications. 2015; 5: 1-5.

[11] Passos JL, Barbosa LCA, Demuner AJ. Chemical characterization of volatile compounds of Lantana camara L. and L. radula Sw. and their antifungal activity. Molecules. 2012; 17: 11447-11455. 
[12] Jitendra P, Kumar GS, Deviprasad SP, Deepika S, Qureshi MS. Phytochemical and antihelmintic evaluation of Lantana camara (L) var, aculeate leaves against Pheretima posthuma. Journal of Global Trends in Pharmaceutical Sciences. 2011; 2: 11-20.

[13] Kirimuhuzya C, Waako P, Joloba M, Odeyek O. The anti-mycobacterial activity of Lantana camara a plant traditionally used to treat symptoms of tuberculosis in SouthWestern Uganda. African Health Sciences. 2009; 9: 40-45.

[14] Ayub A, Saima T, Syed TA, Sabira B, Bina SS, Aqeel A. Antioxidant Activity of the Medicinal Plant Lantana camara leaf, FUUAST Journal of Biology. 2017; 7(2): 227-230.

[15] Silva TSC, Suffredini IB, Ricci EL, Fernandes SRC, Gonçalves VJ, Romoff P, LagoJHG, Bernardi B. Antinociceptive and anti-inflammatory effects of Lantana camara L. extract in mice. Revista Brasileira Plantas Medicinais, Campinas. 2015; 17: 224-229.

[16] Sathisha R, Vyawaharea B, Natarajanb K. Antiulcerogenic activity of Lantana camara leaves on gastric and duodenal ulcers in experimental rats. Journal of Ethnopharmacology. 2011; 134: 195-197.

[17] Rachel RP, Wilson VJ, Bernhard L, Elaine SC, Nicolli BS, Clarice A, Geraldo LGS, Maria ACK. Essential oil from leaves of Lantana camara: a potential source of medicine against leishmaniasis. Brazilian Journal of Pharmacognosy. 2012; 22: 1011-1017.

[18] Sagar L, Sehgal R, Ojha S. Evaluation of antimotility effect of Lantana camara L. var. acuelata constituents on neostigmine induced gastrointestinal transit in mice. BioMed Central Complementary and Alternative Medicine. 2005; 5: 18 .

[19] Mengistu G, Engidawork E, Nedi T. Evaluation of the antidiarrhoeal activity of 80\% methanol extract and solvent fractions of the leaves of Lantana camara linn (Verbenaceae) in mice. Ethiopian Pharmaceutical Journal. 2015; 31: 107-121.

[20] Ghodake PP, Kulkarni AS, Aloorkar NH, Bhosale RR, Harkare B, Kale BB, Osmani RA. In-vitro antispasmodic activity analysis of methanolic leaves extract of Lantana camara Linn. on excised rat ileum. Journal of Pharmacognosy and Phytochemistry. 2013; 2(3): 66-71.

[21] National Institute of Health (NIH). Committee for the update of the guide for the Care and use of laboratory animals. Washington (DC): National Academies Press (US). 2011.

[22] OECD (Organization for Economic Co-operation and Development). OECD Guidelines for the Testing of Chemicals / Section 4: Health Effects Test No.423: Paris: Acute Oral Toxicity - Acute Toxic Class Method. 2002.

[23] Aziz Abdullah. Qualitative phytochemical screening and evaluation of anti-inflammatory, analgesic and antipyretic activities of Microcos paniculata barks and fruits. Journal of integrative Medicine. 2015; 13(3): 173184.

[24] Kalita S, Kumar G, Karthik L, Rao KVB, Rao VB. Phytochemical composition and in vitro hemolytic activity of Lantana camara (Verbenaceae) leaves. Pharmacologyonline. 2011; 1: 59-67.

[25] Qnais EY, Elokda AS, Ghalyun YA, Abdulla FA. Antidiarrhea activity of the aqueous extract of Punica granatum (Pomegranate) peels. Pharmaceutical Biology. 2007; 45: 715-20.

[26] Akuodor GC, Nwobodo NN, Megwas AU, Akpan JL, Nwachukwu DC, Asika EC, Chilaka, KC. Antidiarrhoeal and antimicrobial activities of the ethanol extract from the Icacina senegalensis root bark. Journal of basic and clinical physiology and pharmacology. 2018; 29(2): 211-216.

[27] Akuodor GC, Idris-Usman M, Ugwu TC, Akpan JL, Irogbeyi LA, Iwuanyanwu TC, Osunkwo UA. Ethanolic leaf extract of Verbena hastate produces antidiarrhoeal and gastrointestinal slowing effects in albino rats. Journal of Medicinal Plants Research. 2010; 4: 1624-1627.

[28] Akuodor GC, Muazzam I, Usman-Idris M, Megwas UA, Akpan JL, Chilaka KC, Okoroafor DO, Osunkwo UA. Evaluation of the antidiarrheal activity of methanol leaf extract of Bombax Buonopozense in rats. Ibnosina Journal of Medicine and Biomedical Sciences. 2011; 3(1): 15-20.

[29] Alaba DEC, Etor VFD, Llacuna EJC, Mabao EP, Nangcas DMC, Salvana PAA, Simene RA. The Effect of Kantutay Leaves (Lantana camara L.) crude extract on the defecation frequency of male white mice. Advancing Pharmacy Research. 2014; 1: 37-46.

[30] Kulkami SR, Pandit AB. Enzymatic hydrolysis of castor oil: an approach for rate enhancement and enzyme economy. Indian Journal of Biotechnology. 2005; 4: 241-245. 
[31] Izzo AA, Mascolo N, Capasso R, Germano MP, Depasquel R, Capasso F. Inhibitory effect of cannabinoid agonist on gastric emptying in the rat. Archives of Pharmacology. 1999; 360: 221-223.

[32] Tunaru S, Althoff TF, Nüsing RM, Diener M, Offermanns S. Castor oil induces laxation and uterus contraction via ricinoleic acid activating prostaglandin EP3 receptors. Proceedings of the National Academy of Sciences. 2012; 109: 9179-9184.

[33] Cline WS, Lorenzsonn V, Benz L, Bass P, Olsen WA. The effects of sodium ricinoleate on small intestinal function and structure. Journal of Clinical Investigation. 1976; 58: 380-390.

[34] Gaginella TS, Philips SF, Dozois RR, Go VLW. Stimulation of adenylate cyclase in homogenates of isolated intestinal epithelial cells from hamsters. Effects of gastrointestinal hormones, prostaglandins and deoxycholine and recinoleic acid. Gastroenterology. 1978; 74: 11-15.

[35] Matias JR, Martin JL, Burns TW. Ricinoleic acid effect on the electrical activity of the small intestine in rabbits. The Journal of Clinical Investigation. 1978; 61: 640-644.

[36] Coupar IM. Opioid action of the intestine: The importance of the intestinal mucosa. LifeScience. 1987; 41: 917925.

[37] Sharma HL, Sharma KK. Opioid analgesics and opioid antagonists. Principles of Pharmacology. 2nd edition. Hyderabad: Paras Medical Publishers. 2011.

[38] Tadesse T, Hailu E, Gurmu E, Mechesso F. 'Experimental assessment of antidiarrheal and antisecretory activity of $80 \%$ methanolic leaf extract of Zehneria scabra in mice', BMC Complementary and Alternative Medicine. 2014; 14: 460.

[39] Murek M, Kopic S, Geibel J. 'Evidence for intestinal chloride secretion', Experimental Physiology. 2010; 95 : 471-478.

[40] Bardal S, Waechter J, Martin D. “Gastroenterology,” in Applied Pharmacology. Saunders, Pennsylvania, Pa, USA. 2010; 177-188.

[41] Palombo EA. Phytochemicals from traditional medicinal plants used in the treatment of diarrhea: modes of action and effects on intestinal function. Phytotherapy Research. 2006; 20: 717-724.

[42] Mascolo N, Izzo AA, Barbato F, Capasso F. Inhibitors of nitric oxide synthetase prevent castor-oil-induced diarrhea in the rat. British Journal of Pharmacology. 1993; 108: 861- 864.

[43] Mascolo N, Izzo AA, Autore G, Barbato F, Capasso F. Nitric oxide and castor oil induced diarrhea. Journal of Pharmacology and Experimental Therapeutics. 1994; 268: 291-295.

[44] Izzo AA, Gaginella TS, Mascolo N, Borreli F, Capasso F. NG-Nitro-l-arginine methyl ester reduces senna- and cascara-induced diarrhea and fluid secretion in the rat. European Journal of Pharmacology. 1996; 301: 137-142.

[45] Basu S, Hazra B. Evaluation of nitric oxide scavenging activity, in vitro and ex vivo of selected medicinal plants traditionally used in inflammatory diseases. Phytotherapy Research. 2006; 20: 896-90.

[46] Duarte J, Francisco V, Perez-Vizcaino F. Modulation of nitric oxide by flavonoids. Food Function. 2014; 5: 16531668.

[47] Raso GM, Meli R, Carlo GD, Pacilio M, Carlo RD. Inhibition of inducible nitric oxide synthase and cyclooxygenase2 expression by flavonoids in macrophage J774A.1 Life Sciences. 2001; 68: 921-931.

[48] Ishii R, Saito K, Horie M, Shibano T, Kitanaka S, Amano F. Inhibitory effects of hydrolyzable tannins from Melastoma dodecandrum Lour on nitric oxide production by a murine macrophage-like cell line, RAW264.7, activated with lipopolysaccharide and interferon-gamma. Biological and Pharmaceutical Bulletin. 1999; 22: 64753.

[49] Kondo Y, Takano F, Hojo H. Inhibitory effect of bisbenzyl isoquinoline alkaloids on nitric oxide production in activated macrophages. Biochemistry and Pharmacology. 1993; 46: 1887-1892.

[50] Jang DS, Min HY, Jeong YH, Lee SK, Seo E. Di- and sesqui-terpenoids isolated from the pods of Sindora sumatrana and their potential to inhibit lipopolysaccharide induced nitric oxide production. Archives of Pharmacal Research. 2004; 27: 291-294.

[51] Guyton AC, Hall JE. Text book of Medical Physiology, 10th edition. Harcourt India private limited 2001; 720 $-721$. 
[52] Belemtougri RG, Constantin B, Cognard C, Raymond G, Sawadogo L. Effects of two medicinal plants, Psidium juajava L. (Myrtaceae) and Diospyros mespiliformis L. (Ebenaceae) leaf extracts on rat skeletal muscle cells in primary culture. Journal of Zhejiang University Science. 2006; 7: 56-63.

[53] Ashok PK, Upadhyay K. Tannins are astringent. Journal of Pharmacognosy and Phytochemistry. 2012; 1: 45.

[54] Jalilzadeh-Amin G, Maham M. The application of 1, 8-cineole, a terpenoid oxide present in medicinal plants, inhibits castor oil-induced diarrhea in rats. Pharmaceutical Biology. 2015; 53: 594-599. 